\title{
PEMAHAMAN MASYARAKAT KECAMATAN RAPPOCINI TENTANG KELUARGA SAKINAH
}

\author{
Syamsir Sulaiman \\ Muliaty Amin \\ Nurhidayat Muhammad Said \\ ASN pada Kementerian Agama Kota Makassar \\ syamsir.sulaiman@gmail.com
}

\begin{abstract}
Abstrak: Tulisan ini membahas tentang pemahaman masyarakat Kecamatan Rappocini tentang keluarga sakinah. Jenis penelitian ini adalah penelitian yang bersifat kualitatif untuk mengungkapkan secara mendalam tentang pemahaman masyarakat Kecamatan Rappocini tentang keluarga sakinah. Pendekatan yang digunakan adalah pendekatan dakwah dan pendekatan sosiologi dakwah. Sumber data dalam penelitian ini adalah pasangan suami istri, dan tokoh masyarakat di Kecamatan Rappocini Kota Makassar. Data dikumpulkan di metode observasi, wawancara, dan dokumentasi dengan instrumen penelitian berupa pedoman observasi, pedoman wawancara dan alat dokumentasi dalam bentuk kamera. Data diolah dan dianalisis dengan reduksi data, penyajian data, dan penarikan kesimpulan.

Hasil penelitian ini menunjukkan bahwa pemahaman masyarakat tentang keluarga sakinah sebahagian besar sudah memahami, namun dalam mengaflikasikan dalam kehidupan sehari-hari masih terdapat rumah tangga yang belum mencapai taraf kehidupan keluarga yang sejahtera sakinah mawaddah warahmah. Disebabkan oleh berbagai faktor dan hambatanhambatan yang sering terjadi dalam membina rumah tangga. Diharapkan bagi calon pengantin agar mampu mengaplikasikan ilmu dan wawasan pengetahuan yang diperoleh melalui bimbingan perkawinan yang dilaksanakan di Kantor Urusan Agama Kecamatan Rappocini Kota Makassar sehingga tujuan dari pernikahan itu yakni menginginkan keluarga yang sakinah mawaddah warahmah dapat tercapai. Juga diharapkan kepada para penyuluh dan seluruh yang terkait didalam pembinaan perkawinan bagi calon pengantin agar mampu mentransfer ilmu dan pengalaman sebagai bekal dalam menjalani kehidupan rumah tangga.
\end{abstract}

\section{Kata Kunci: Pemahaman Masyarakat; Kecamatan Rappocini; Keluarga Sakinah}

\section{PENDAHULUAN}

Salah satu naluri yang dimiliki manusia adalah kecenderungan kepada lawan jenis. Naluri ini unsur fitrah dari eksistensi manusia dimuka bumi yang erat kaitannya dengan kelangsungan hidup dan kelestarian generasi. Karenanya, panggilan naluri tersebut harus direspon secara tepat. Kalau tidak, dampak negatifnya tidak saja akan menimpa kehidupan pribadi seseorang, melainkan juga mengacaukan tatanan kehidupan sosial.

Sebagai agama yang hanif, Islam tidak menyukai sikap hidup yang berusaha mengingkari atau tidak memenuhi naluri tersebut dengan memilih hidup 
membujang. Sikap hidup seperti itu jelas bertentangan dengan kondisi obyektif manusia, bahkan memaksa manusia untuk menanggung beban diluar kemampuannya sebagaimana didalam sebuah hadis Rasulullah saw. bersabda:

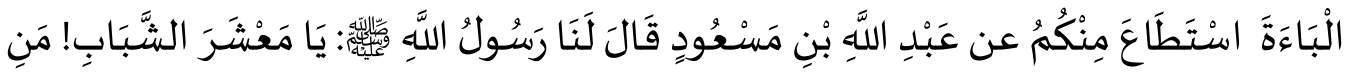

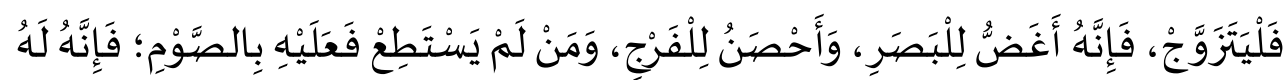

Terjemahnya:

"Dari Abdillah bin Mas'ud, Rasulullah saw berkata: Wahai sekalian pemudah, barangsiapa yang sudah mampu diantara kamu hendaklah menikah secepatnya" (Bukhari: 50-30, Muslim: 1425)

Disisi lain, Islam juga melarang manusia bersikap seperti mahluk lainnya yang menyalurkan naluri tersebut secara bebas atau bahkan liar. Sebab walau bagaimanapun manusia dalam suatu lingkungan masyarakat tidak akan aman dan sehat jika menganut paham permissivisme (paham serba boleh). Terbukti free sex atau seks bebas telah menorehkan banyak sekali noda hitam pada lembar peradam manusia. Merebaknya penyakit kelamin, menjamurnya pelacuran, meningkatnya jumlah penderita gangguan kejiwaan, mewabahnya penyimpangan perilaku seksual, dan berbagai penyakit sosial lainnya, menjadi bukti bahwa seks bebas hanya melahirkan sebuah kehidupan yang porak-poranda.

Islam telah mensyariaatkan perkawinan sebagai cara yang sehat dan sah guna pemuasan naluri tersebut. Hal ini berlaku bagi manusia biasa, pemimpin agama bahkan para Nabi. Tak ada sistem sosial yang sanggup mengabaikan lembaga perkawinan. Sebab perkawinan erat kaitannya dengan kepuasan jiwa, keselamatan moral dan penataan kehidupan sosial. Dalam perspektif ini perkawinan merupakan perintah agama banyak ayat Al-qur'an dan hadits yang menerangkan tentang hal ini. Sebagaimana firman Allah dalam QS al-Nūr/24:32.

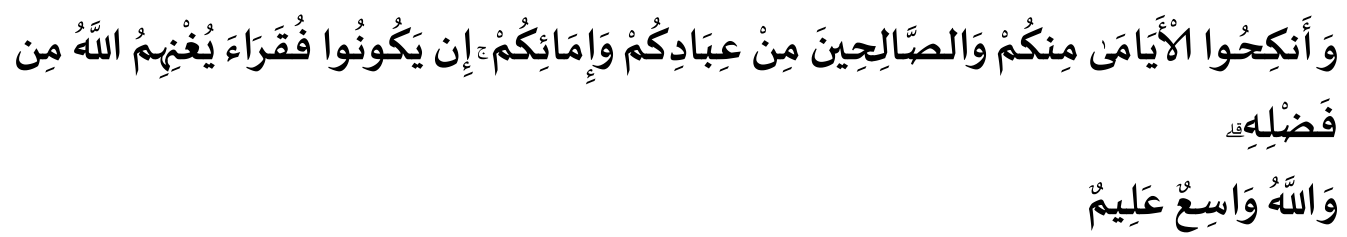

Terjemahnya:

Dan kawinkanlah orang-orang yang sendirian diantara kamu, dan orangorang yang layak (kawin) dari hamba-hamba sahayamu yang lelaki dan hamba-hamba sahayamu yang perempuan. Jika mereka miskin Allah akan memampukan mereka dengan karunia-Nya. Dan Allah Maha Luas (pemberian-Nya) lagi Maha Mengetahui".'

\footnotetext{
${ }^{1}$ Kementerian Agama RI, Al-Quran dan Terjemahan, Direktorat Jenderal Bimbingan Masyarakat Islam, Direktorat Urusan Agama Islam dan Pembinaan Syariah (Cet I; Jakarta: PT. Sinergi Pustaka Indonesia, 2012), h. 494.
} 
Sebagai perintah agama tentu saja setiap muslim harus melaksanakannya. Akan tetapi perkawinan seharusnya dilakukan dengan penuh tanggung jawab, yang antara lain adanya berbagai kesiapan, baik fisik, mental maupun ekonomi. Memang tidak semua orang memiliki kemampuan untuk menikah, Namun bukan berarti Islam mengizinkan seseorang untuk hidup membujang. Bagi orang-orang yang belum mampu untuk menikah. Islam menganjurkan untuk menahan diri, sampai Allah menganugerahkan kemampuan kepada mereka.

Di samping untuk pemuasan naluri tersebut, perkawinan juga memeberi kesempatan kepada manusia untuk menunaikan tanggung jawab kekhalifaannya dimuka bumi ini. Perekonomian merupakan gerbang menuju terbentuknya keluarga yang menjadi elemen dasar dari sebuah masyarakat. Kemajuan dan kemakmuran suatu masyarakat atau sebaliknya, keterbelakangan, kebodohan dan kehancuran suatu negara merupakan cerminan dari keluarga-keluarga yang membentuknya.

Keluarga adalah umat kecil yang masing-masing anggotanya terikat oleh tanggung jawab untuk melaksakan fungsinya. Dengan kata lain, perkawinan merupakan pembuka sebuah lingkungan kerja yang memberikan kesempatan kepada manusia untuk menunaikan tanggung jawab sosialnya, yakni pembentukan dan pembinaan generasi ke arah terciptanya masyarakat yang dicita-citakan.

Perkawinan merupakan suatu ikatan psikologis, sosiologis dan biologis antara dua pasang manusia yang berlainan jenis, serta memiliki hasrat dan tujuan bersama antara suami istri guna mencapai ketentraman dan kesejahteraan lahir dan bathin serta kebahagiaan dunia dan akhirat. Namun dalam mencapai hal tersebut tak semudah yang kita bayangkan, terkadang dalam menjalani hubungan perkawinan atau membangun mahligai rumah tangga itu tak semudah membalik telapak tangan. Tak sedikit perkawinan yang berjalan baru dibangun setahun baru berjalan, lalu retak dan berantakan. Bahkan yang sudah berpuluh-puluh tahunpun kadangkala terpaksa harus memutuskan untuk berpisah.

Dalam kehidupan berkeluarga atau menempuh kehidupan dalam perkawinan adalah harapan dan niat yang wajar dan sehat dari setiap anak muda dan remaja dalam memelihara dan membina keluarga hingga mencapai taraf kebahagiaan dan kesejahteraan yang selalu didambakan oleh setiap pasangan suami istri tergantung kedua belah pihak. Keluarga yang bisa mencapai kebahagiaan dan kesejahteraan itu yang disebut dengan keluarga sakinah.

Untuk membangun sebuah mahligai keluarga tidak cukup dengan hanya bermodalkan perasaan, materi, apalagi modal nekat. Islam telah menuntun kepada umatnya untuk membangun keluarga sakinah setelah perkawinan dilaksanakan. Islam juga menganjurkan kepada para calon suami atau calon istri untuk memilih dengan cara yang sakinah. Adakalanya seorang calon mempelai mempersiapkan dengan baik, diantaranya dengan konseling perkawinan. Konseling perkawinan (marriage counseling) adalah upaya membantu pasangan calon suami istri oleh konselor profesional sehingga mereka dapat berkembang dan mampu memecahkan masalah dengan cara yang saling menghargai, toleransi, dan dengan 
komunikasi yang penuh pengertian, sehingga tercapai motivasi berkeluarga, perkembangan, kemandirian dan kesejahteraan seluruh anggota keluarga.

Secara kodrati, manusia hidup memerlukan bantuan orang lain. Bahkan, manusia baru akan "menjadi manusia" ketika berada dalam lingkungan dan berhubungan dengan manusia. Dengan kata lain, secara kodrati manusia merupakan makhluk sosial. Tuntutan saling kenal-mengenal yang harus dilakukan antara masing-masing orang sebagai manifestasi interaksi adalah bagian dari proses bimbingan yang harus dijalankan oleh orang lain kepada saudaranya untuk bisa menjaga dirinya dari hal-hal yang bersifat negatif dan melakukan hal-hal yang positif. Dinamika tersebut dapat kita tengok pada lingkungan Kantor Urusan Agama pada umumnya dan khususnya Kantor Urusan Agama kecamatan Rappocini atau dapat kita ketahui dengan istilah KUA.

Dalam lembaga tersebut melayani semua umat muslim untuk melakukan pernikahan secara sah dengan cara mencatatkan pernikahan yang dilakukan orang yang akan melangsungkan pernikahan di Kantor Urusan Agama (KUA).

Dalam Kantor Urusan Agama Kecamatan se-Kota Makassar khususnya di Kantor KUA Kecamatan Rappocini terdapat Penyuluh Agama Islam yang bertugas untuk memberikan penerangan seputar bimbingan perkawinan tentang bagaimana menjalin hubungan suami istri yang ideal dan dapat menempuh keluarga yang sakinah. Dalam lembaga pemerintah tersebut seorang penyuluh memberikan bimbingan pernikahan dan memberikan pembinaan terhadap pasangan calon suami istri yang hendak menikah. Namun kenyataannya masih terdapat perceraian yang dilakukan oleh pasangan suami istri. Dalam hal ini yang lebih dominan menggugat adalah dari pihak perempuan sehingga yang menjadi korban dari perceraian tesebut yakni anaknya yang broken home.

\section{KAJIAN TEORETIS}

Keluarga sakinah adalah keluarga yang dibina atas perkawinan yang sah, mampu memenuhi hajat hidup spritual dan material secara layak dan seimbang, diliputi suasana kasih sayang antara anggota lingkungannya dengan selaras, serasi, serta mampu mengamalkan, menghayati dan memperdalam nilai-nilai keimanan, ketaqwaan dan akhlak yang mulia. Adapun pengertian sakinah oleh beberapa ulama antara lain:

a. Muhammad Rasyid Ridha mengartikan sakinah sebagai sikap jiwa yang bersumber dari suasana ketenangan, sakiah lawan dari kegoncangan batin dan kekalutan jiwa.

b. Al-Isfahan, ahli fiqhi dan tafsir mengartikan sakinah dengan tidak adanya rasa gentar dalam menghadapi suasana.

c. Al-Jurjani mengartikan sakinah sebagai adanya ketentraman dalam hati saat datangnya sesuatu yang tidak diduga, dibarengi satu nur (cahaya) dalam hati, yang memberi ketenangan dan ketentraman jiwa, dan merupakan keyakinan berdasarkan panca indra (ainul yakin). 
d. Sebagain ulama ada yang meyamakan sakinah dengan kata rahma dan tuma'ninah yang berarti tenang, tidak gunda dalam melaksanakan ibadah ${ }^{2}$

Sifat keluarga yang dikehendaki oleh fitrah dan agama yaitu sakinah adapun pengertian sakinah dalam bahasa arab mempunyai 11 (sebelas) arti yaitu bersatu, berkumpul, rukun, akrab, bersahabat intim, saling percaya, ramah tamah, jinak, sama-sama senang dan saling meredakan. ${ }^{3}$

Dari arti etimologi di atas, kita dapat memperoleh gambaran yang jelas bahwa keluarga sakinah yang dikehendaki oleh fitrah manusia dan agama ialah terwujudnya suasana keluarga yang bersatu tujuan, selalu dapat berkumpul dengan baik, rukun dan akrab dalam kehidupan sehari-hari, penuh persahabatan intim, saling menghargai, saling mempercayai dan bersikap ramah tamah antara satu dengan yang lain, sehingga dapat diibaratkan seperti burung merpati jinak yang berkumpul. Dengan suasana semacam itu terciptalah perasaan sama-sama senang dan berupaya untuk meredam emosi yang negatif sehingga kehidupan keluarga membawa kebaikan bagi semua anggota keluarga dan berdampak ketenangan bagi lingkungannya sehingga dapat tercipta suasana salam (damai dan sejahtera) serta aman di tengah masyarakat. Inilah yang dimaksud dengan keluarga sakinah penuh berkah.

Kehidupan berkeluarga atau menempuh kehidupan dalam perkawinan adalah harapan dan niat yang wajar dan sehat dari setiap anak muda dan remaja dalam masa pertumbuhannya. Pengalaman dalam kehidupan menunjukkan bahwa membangun keluarga itu mudah, tetapi memelihara dan membina keluarga hingga mencapai taraf kebahagiaan dan kesejahteraan yang selalu didambakan oleh setiap pasangan suami istri sangat sulit. keluarga yang bisa mencapai kebahagiaan dan kesejahteraan itu yang disebut dengan keluarga sakinah. ${ }^{4}$ Untuk mecapai suatu kebahagiaan diperlukan pula adanya saling pengertian dan saling memahami antara suami dan istri agar hubungan tersebut bisa tetap terjaga sehingga pada akhirnya akan membentuk keluarga yang sakinah mawadah warahmah. Rūm/30:21.

Penggunaan kata sakinah sebagaimana firman Allah dalam QS al-

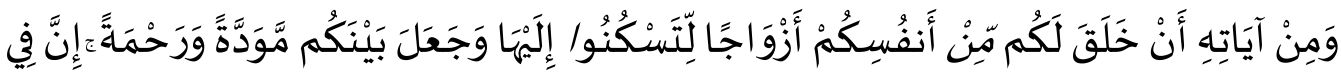

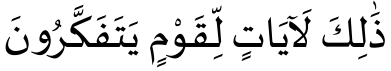

Terjemahnya:

"Dan di antara tanda-tanda kekuasaan-Nya ialah Dia menciptakan untukmu isteri-isteri dari jenismu sendiri, supaya kamu cenderungdan

\footnotetext{
${ }^{2}$ Sofyan Hasdan, Merekat Kebahagiaan Keluarga (Cet. I; Jakarta: Khasanah Manusia Nusantara, 2004).

${ }^{3}$ Thalib, Konsep Islami Pembinaan Keluarga Sakinah Penuh Berkah (Cet I; Bandung: Irsyat Baitus Salam, 1999), h. 27.

${ }^{4}$ Ahmad Atabik, Dari Konseling Perkawinan Menuju Keluarga Samara, dalam Jurnal Bimbingan Konseling Islam, Konseling Religi, Jurusan Dakwah, Volume 4, Nomor 2, 2013, h. 162.
} 
merasa tentram kepadanya, dan dijadikan-Nya diantaramu rasa kasih sayang. Sesungguhnya pada yang demikian itu benar-benar terdapat tanda-tanda bagi kaum yang berfikir".

Menurut pandangan Ahmad Atabik tentang Litaskunu ilaiha, yang artinya bahwa Tuhan menciptakan perjodohan bagi manusia agar yang satu merasa tentram terhadap yang lain. Dalam bahasa arab, kata sakinah di dalamnya terkandung arti tenang, terhormat, aman, penuh kasih sayang, mantap dan memperoleh pembelaan. Pengertian ini pula yang dipakai dalam ayat-ayat AlQur'an dan Hadis dalam kontes kehidupan manusia. Jadi keluarga sakinah adalah kondisi yang sangat ideal dalam kehidupan keluarga, dan yang ideal biasanya jarang terjadi, oleh karena itu ia tidak terjadi mendadak, tetapi ditopang oleh pilarpilar yang kokoh, yang memerlukan perjuangan serta butuh waktu serta pengorbanan terlebih dahulu.

Istilah sakinah, mawaddah, wa rahmah cukup populer di Indonesia. Ia sering muncul dalam surat undangan perkawinan dan doa-doa yang dipanjatkan bagi calon mempelai dan pengantin baru. Adapun istilah-istilah ini sebagai berikut:

Sakinah (سكين) secara sederhana dapat diterjemahkan sebagai kedamaian. Berdasarkan ayat-ayat al-Qur'an (QS al-Baqarah/9:26 dan 40; QS al-Fath/48, 18 dan 26), saakinah atau kedamaian itu didatangkan oleh Allah kedalam hati para Nabi dan orang-orang yang beriman agar tabah dan tidak gentar menghadapi rintangan apapun. Jadi berdasarkan arti sakinah pada ayat-ayat tersebut, maka sakinah dalam keluarga dapat dipahami sebagai keadaan yang tetap tenang meskipun menghadapi berbagai banyak rintangan dan ujian kehidupan.

Mawaddah (مودة) Quraish Shihab dalam bukunya Membumikan Al-Qur'an menjelaskan bahwa kata ini secara sederhana, dari segi bahasa, dapat diterjemahkan sebagai "cinta". Istilah ini bermakna bahwa orang yang memiliki cinta dihatinya akan lapang dadanya, penuh harapan, dan jiwanya akan selalu menjauhkan diri dari keinginan buruk atau jahat, ia akan senantiasa cinta baik di kala senang maupun susah atau sedih. ${ }^{5}$

Mawaddah (مودة) artinya perasaan kasih sayang, yang dimiliki seseorang sebagai fitrah ini muncul karena beberapa sebab, cantik/tampan, harta, keturunan dan agama.

Warahmah (ورحمة) Secara sederhana dapat diterjemahkan sebagai "kasih Sayang". Istilah ini bermakna keadaan jiwa yang dipenuhi dengan kasih sayang. Rasa kasih sayang ini menyebabkan seseorang berusaha akan memberikan kebaikan, kekuatan dan kebahagiaan bagi orang lain dengan cara-cara yang lembut dan penuh kesabaran.

\footnotetext{
${ }^{5}$ M.Quraish Shihab, Membumikan Al-Qur'an (Cet. XI; Bandung: Mizan, 1995)
} 
Warahmah (ورحمة) artinya ampunan, rahmat, rezeki dan karunia dari Allah Swt yang terbesar pada rumah tangga yang terjaga rasa cinta, kasih sayang dan juga kepercayaan.

Keluarga yang mendapatkan rahmah melalui proses sebagai berikut: 1) Saling membutuhkan antara kedua belah pihak; 2) Saling menutupi kekurangan masing-masing; 3) Saling memahami antara suami istri dan anggota keluarga yang lainnya; dan 4) Saling memberi pengertian.

Jadi keluarga ideal adalah keluarga yang mampu menjaga kedamaian, dan memiliki cinta dan kasih sayang. Unsur cinta dan kasih sayang harus ada untuk saling melengkapi agar pasangan dapat saling membahagiakan. Kebahagian mungkin akan terasa pincang jika hanya memiliki salah satunya. Cinta (mawaddah) adalah perasaan cinta yang melahirkan keinginan untuk membahagiakan dirinya. Ungkapan yang bisa menggambarkannya adalah "Aku ingin menikahimu karena aku bahagia bersamamu". Sedangkan kasih sayang (rahmah) adalah perasaan yang melahirkan keinginan untuk membahagiakan orang yang dicintainya. Ungkapan ini menggambarkan rahmah, "Aku ingin menikahimu karena aku ingin membuatmu bahagia”. Pasangan suami istri memerlukan mawaddah dan rahmah sekaligus, yakni perasaan cinta yang melahirkan keinginan untuk membahagiakan dirinya sendiri sekaligus pasangannya dalam suka maupun duka. Tampa menyatukan keduanya, akan muncul kemungkinan pasangan suami dan istri hanya peduli pada kebahagiaan dirinya masing-masing atau memanfaatkan pasangannya demi kebahagiaannya sendiri tampa peduli pada kebahagiaan pasangannya. Ringkasnya, mawaddah dan rahmah adalah landasan batiniah atau dasar ruhani bagi terwujudnya keluarga yang damai secara lahir dan batin. ${ }^{6}$

Yang dimaksud dengan rasa kasih dan sayang adalah rasa tentram dan nyaman bagi jiwa rasa dan kemantapan hati menjalani hidup serta rasa aman dan cinta kasih yang terpendam jauh dalam lubuk hati manusia sebagai hikmah yang dalam dari nikmat Allah kepada makhluk-Nya yang saling membutuhkan.

Keluarga sakinah berarti keluarga yang tenang atau keluarga yang tentram. Sebuah keluarga bahagia, sejahtera lahir dan batin, hidup cinta-mencintai dan kasih-mengasihi, di mana suami bisa membahagiakan istri, sebaliknya, istri bisa membahagiakan suami, dan keduanya mampu mendidik anak-anaknya menjadi anak-anak yang shaleh dan shalehah, yaitu anak-anak yang berbakti kepada orang tua, kepada agama, masyarakat, dan bangsanya. Selain itu, keluarga sakinah juga mampu menjalin persaudaraan yang harmonis dengan sanak famili dan hidup rukun dalam bertetangga, bermasyarakat, dan bernegara.

Dari beberapa definisi di atas, maka dapat diartikan bahwa keluarga sakinah adalah keluarga yang harmonis, penuh kasih sayang antara suami istri,

${ }^{6}$ Subdit Bina Keluarga Sakinah, Fondasi Keluarga Sakinah, Direktorat Bina KUA \& Keluarga Sakinah, Ditjen Bimas Islam Kemenag RI, 2017. h. 10-13 
saling menghormati dan menghargai, mampu memberikan ketenangan dan meningkatkan ketaqwaan kepada Allah swt. ${ }^{7}$

Oleh karena itu rumah tangga yang penuh barokah itu adalah rumah tangga yang tujuannya adalah mengharapkan keridhoan Allah swt. yang hariharinya disisi dengan kesungguhan untuk mendekatkan diri kepada Allah, yang hartanya dicari dan dia nafkahkan di jalan Allah, yang rumahnya disukai oleh Allah, yang isinya tidak membuat murkah Allah. ${ }^{8}$ Rumah tangga yang menjadikan Allah sebagai tujuan, pegangan, penggantung hidupnya dan dibuktikan dengan ketaatan. Inilah rumah tangga yang benar-benar akan merasakan ketentraman.

Kementerian Agama Republik Indonesia sebagai kementerian yang bertanggung jawab atas pembinaan perkawinan dan keluarga juga mempunyai kriteria dan tolak ukur keluarga sakinah. Keduanya tertuang dalam Surat Keputusan Menteri Agama Republik Indonesia Nomor 3 Tahun 1999 tentang pembinaan gerakan keluarga sakinah, dengan kriteria sebagai berikut: ${ }^{9}$

a. Keluarga pra sakinah yaitu keluarga-keluarga yang di bentuk bukan melalui ketentuan perkawinan yang sah, tidak dapat memenuhi kebutuhan dasar spiritual dan material (kebutuhan pokok) secara minimal, seperti keimanan, shalat, zakat fitrah, puasa, sandang, pangan, papan dan kesehatan.

Tolak Ukurnya:

1. Keluarga yang dibentuk melalui perkawinan yang tidak sah

2. Tidak sesuai ketentuan perundang-undangan yang berlaku

3. Tidak memiliki dasar keimanan

4. Tidak melakukan shalat wajib

5. Tidak mengeluarkan zakat fitrah

6. Tidak menjalankan puasa wajib

7. Tidak tamat SD, dan tidak dapat baca tulis

8. Termasuk kategori fakir dan miskin

9. Berbuat asusila

10. Terlibat perkara-perkara kriminal

b. Keluarga sakinah 1: yaitu keluarga-keluarga yang dibangun di atas perkawinan yang sah dan telah dapat memenuhi kebutuhan spiritual dan material secara minimal tetapi masih belum dapat memenuhi kebutuhan sosial psikologisnya, seperti kebutuhan pendidikan, bimbingan keagamaan dan keluarganya, mengikuti intraksi sosial keagamaan dan lingkungannya.

\footnotetext{
${ }^{7}$ Khalilah Mardiyanto, Romantika Perkawinan (Cet. I; Putra Pelajar, 2000), h. 98

${ }^{8}$ Abdullah Gymanstiar, Membangun Keluarga (Cet. II; Bandung: MQS Pustaka Grafika, 2002), h. 14

${ }^{9}$ Adib Machrus dkk

, Fondasi Keluarga Sakinah (Subdit Bina Keluarga Sakinah, Direktorat Bina KUA \& Keluarga Sakinah, Ditjen Bimas Islam Kemenag RI, 2017), h. 16-19
} 
Tolak Ukurnya:

1. Perkawinan sesuai dengan peraturan syariat dan undang-undang nomor 1 tahun 1974

2. Keluarga memiliki surat nikah atau bukti lain, sebagai bukti perkawinan yang sah

3. Mempunyai perangkat sholat, sebagai bukti melaksanakan sholat wajib dan dasar keimanan

4. Terpenuhi kebutuhan makanan pokok, sebagai tanda bukan tergolong fakir dan miskin

5. Masih sering meninggalkan sholat

6. Jika sakit sering pergi ke dukun

7. Percaya terhadap tahayyul

8. Tidak datang di pengajian atau majelis taklim

9. Rata-rata keluarga tamat atau memiliki ijazah SD

c. Keluarga Sakinah II: yaitu keluarga-keluarga yang dibangun atas perkawinan yang sah dan selain telah dapat memenuhi kebutuhan kehidupannya juga telah mampu memahami pentingnya pelaksanaan ajaran agama serta bimbingan keagamaan dalam keluarga. Keluarga ini juga mampu mengadakan intraksi sosial keagamaan dengan lingkungannya, tetapi belum mampu menghayati serta mengembangkan nilai-nilai keimanan, ketaqwaan dan akhlakul qarimah infaq, zakat, amal jariyah menabung dengan sebagainya.

Tolak Ukurnya:

1. Tidak terjadi perceraian, kecuali sebab kematian atau hal sejenis lainnya yang mengharuskan terjadinya perceraian itu

2. Penghasilan keluarga melebihi kebutuhan pokok, sehingga bisa menabung

3. Rata-rata keluarga memiliki ijazah SLTP

4. Memiliki rumah sendiri meskipun sederhana

5. Keluarga aktif dalam kegiatan kemasyarakatan dan sosial keagamaan

6. Mampu memenuhi standar makanan yang sehat serta memenuhi 4 sehat 5 sempurna

7. Tidak terlibat perkara kriminal, judi, mabuk, prostitusi dan perbuatan amoral lainnya

d. Keluarga sakinah III: yaitu keluarga-keluarga yang dapat memenuhi seluruh kebutuhan keimanan, ketakwaan, akhlakul qarimah sosial psikologis, dan pengembangan keluarganya tetapi belum mampu menjadi suri tauladan bagi lingkungannya

Tolak Ukurnya:

1. Aktif dalam upaya meningkatkan kegiatan dan gairah keagamaan di masjid-masjid maupun keluarga

2. Keluarga aktif dalam mengurus kegiatan keagamaan dan sosial kemasyarakatan 
3. Aktif memberikan dorongan dan motivasi untuk meningkatkan kesehatan ibu dan anak serta masyarakat pada umumnya

4. Rata-rata keluarga memiliki ijazah SMA ke atas

5. Mengeluarkan zakat, infaq, sedekah, dan wakaf senantiasa meningkat

6. Meningkatkan pengeluaran qurban

7. Laksanakan ibadah haji secara baik dan benar, sesuai tuntunan agama dan ketentuan perundang-undangan yang berlaku

e. Keluarga Sakinah III Plus: yaitu keluarga-keluarga yang telah dapat memenuhi seluruh kebutuhan keimanan, ketaqwaan dan akhlakul qarimah secara sempurna, kebutuhan sosial psikologis, dan pengembangannya serta dapat menjadi suri tauladan bagi lingkungannya

Tolak Ukurnya:

1. Keluarga yang telah melaksanakan ibadah haji dan dapat memenuhi kriteria haji yang mabrur

2. Menjadi tokoh agama, tokoh masyarakat dan tokoh organisasi yang dicintai oleh masyarakat dan keluarganya

3. Mengeluarkan zakat, infaq, shadaqah, jariyah, wakaf meningkat baik secara kualitatif maupun kuantitatif

4. Meningkatkan kemampuan keluarga dan masyarakat sekelilingnya dalam memenuhi ajaran agama

5. Keluarga mampu mengembangkan ajaran agama

6. Rata-rata anggota keluarga memiliki ijazah sarjana

7. Nilai-nilai keimanan, ketaqwaan dan akhlakul karimah tertanam dalam kehidupan pribadi dan keluarganya

8. Tumbuh berkembang perasaan cinta kasih sayang secara selaras, serasi dan seimbang dalam anggota keluarga dan lingkungannya

9. Mampu menjadi suri tauladan dalam masyarakat sekitarnya.

\section{Ciri-Ciri Keluarga Sakinah}

Masyarakat Indonesia mempunyai istilah yang beragam terkait dengan keluarga yang ideal. Ada yang menggunakan istilah keluarga sakinah, keluarga sakinah mawaddah wa rahmah (keluarga samara), keluarga sakinah mawaddah wa rahmah dan berkah, keluarga maslahah, keluarga sejahtera dan lain-lain. Semua konsep keluarga ideal dengan nama yang berbeda ini sama-sama mensyaratkan terpenuhinya kebutuhan batiniyah dan lahiriyah dengan baik. Berikut ini disajikan tiga pendapat tentang ciri-ciri keluarga yang ideal tersebut.

Pertama, ada yang berpendapat bahwa ciri keluarga sakinah yang mencakup hal-hal sebagai berikut:

a. Berdiri di atas fondasi keimanan yang kokoh.

b. Menunaikan misi ibadah dalam kehidupan.

c. Mentaati ajaran agama.

d. Saling mencintai dan menyanyangi.

e. Saling menjaga dan menguatkan dalam kebaikan.

f. Saling memberi yang terbaik untuk pasangan. 
g. Musyawarah menyelesaikan masalah.

h. Membagi peran secara berkeadilan.

i. Kompak mendidik anak.

j. Berkontribusi untuk kebaikan masyarakat, bangsa dan negara.

Kedua, Organisasi Muhammadiyah menggunakan istilah keluarga sakinah yang dipahami sebagai keluarga yang setiap anggotanya senantiasa mengembangkan kemampuan dasar fitrah kemanusianannya, dalam rangka menjadikan dirinya sendiri sebagai manusia yang memiliki tanggung jawab atas kesejahteraan manusia dan alam, sehingga anggota keluarga tersebut selalu merasa aman, tentram, damai dan bahagia. Lima cirinya adalah sebagai berikut:

a. Kekuatan/kekuasaan dan keintiman (power and intimacy). Suami dan istri memiliki hak yang sama untuk berpartisipasi dalam pengambilan keputusan, ini adalah dasar penting untuk kedekatan hubungan.

b. Kejujuran dan kebebasan berpendapat (honesty and freedom of expression). Setiap anggota rumah tangga bebas mengeluarkan pendapat, termasuk pendapat yang berbeda-beda. Walaupun berbeda pendapat tetap diperlakukan sama.

c. Kehangatan, kegembiraan dan humor (warmth, joy and humor). Ketika kegembiraan dan humor hadir dalam hubungan keluarga, setiap anggota keluarga akan merasakan kenyamanan dalam berintraksi. Keceraian dan rasa saling percaya diantara komponen keluarga merupankan sumber penting kebahagiaan rumah tangga.

d. Keterampilan organisasi dan negosiasi (organization and negotiating). Mengatur berbagai tugas dan melakukan negosiasi (musyawarah) ketika terdapat bermacam-macam perbedaan pandangan tentang mengenai banyak hal untuk dicarikan solusi terbaik.

e. Sistem nilai (value system) yang menjadi pegangan bersama nilai moral keagamaan yang dijadikan sebagai pedoman seluruh komponen keluarga merupakan acuan pokok dalam melihat dan mehamami realitas kehidupan serta sebagai rambu-rambu dalam mengambil suatu keputusan.

Ketiga, Nahdatul Ulama menggunakan istilah keluarga maslahah (mashalihul usrah), yaitu keluarga yang dalam hubungan suami-istrib dan orangtua-anak menegakkan prinsip-prinsip keadilan (i'tidal), keseimbangan (tawassun), moderat (tawasuth), toleransi (tasamuh) dan amar ma'ruf nahi munkar, berakhlak karimah, sakinah mawaddah wa rahmah, sejahtera lahir batin, serta berperan aktif mengupayakan kemaslahatan lingkungan sosial dan alam sebagai perwujudan Islam rahmatan lil alamin.

Keluarga maslahah memiliki ciri-ciri sebagai berikut:

a. Suami dan istri yang saleh, yakni bisa mendatangkan manfaat dan faedah bagi dirinya, anak-anaknya dan lingkungannya sehingga darinya tercermin prilaku dan perbuatan yang bisa menjadi tauladan (uswatun hasanah) bagi anak-anaknya maupun orang lain. 
b. Anak-anaknya baik (abrar), dalam arti berkualitas, berakhlak mulia, sehat ruhani dan jasmani, produktif dan kreatif sehingga pada saatnya dapat hidup mandiri dan tidak menjadi beban orang lain atau masyrakat.

c. Pergaulannya baik, maksudnya pergaulan anggota keluarga itu terarah, mengenal lingkungan yang baik dan bertetangga dengan baik tampa mengorbankan prinsip dan pendirian hidupnya.

Berkecukupan rezki (sandang, pangan dan papan), artinya tidak harus kaya dan berlimpah harta, yang penting bisa membiayai hidup dan kehidupan keluarganya, dari kebutuhan sandang, papan dan pangan, biaya pendidikan dan ibadahnya.

\section{METODOLOGI PENELITIAN}

Jenis penelitian ini adalah penelitian yang bersifat kualitatif untuk mengungkapkan secara mendalam tentang pemahaman masyarakat Kecamatan Rappocini tentang keluarga sakinah. Pendekatan yang digunakan adalah pendekatan dakwah dan pendekatan sosiologi dakwah. Sumber data dalam penelitian ini adalah pasangan suami istri, dan tokoh masyarakat di Kecamatan Rappocini Kota Makassar. Data dikumpulkan di metode observasi, wawancara, dan dokumentasi dengan instrumen penelitian berupa pedoman observasi, pedoman wawancara dan alat dokumentasi dalam bentuk kamera. Data diolah dan dianalisis dengan reduksi data, penyajian data, dan penarikan kesimpulan.

\section{HASIL PENELITIAN DAN PEMBAHASAN}

Pemahaman masyarakat Kecamatan Rappocini tentang pembinaan keluarga sakinah dalam penelitian ini ditilik dalam beberapa aspek, yakni pendidikan dan sosial, terpenuhinya sandang dan pangan, dan pelaksanaan keagamaan.

Sektor pendidikan sangat menentukan keberhasilan dalam rumh tangga, sehingga dengan adanya sarana pendidikan sangat membantu masyarakat dalam mewujudkan kehidupan yang lebih baik, jumlah sarana pendidikan di Kecamatan Rappocini sebanyak 118 yang meliputi 29 taman kanak-kanak, 48 Sekolah Dasar, 19 SLTP dan 22 SLTA. Titik berat pelaksanaan pendidikan di Kecamatan Rappocini mengacu padaprogram pendidikan Kota Makassar. Keberhasilan pada sektor pendidikan dan sosial sangat menentukan terbentuknya keluarga yang sejahtera, sakinah mawaddah warahmah.

Menurut Syarifuddin bahwa keluarga sakinah adalah merupakan keluarga yang selalu diberikan kedamaian hati, dilapisi dengan kasih sayang dan mendapat rahmat dari Allah swt. ${ }^{10}$

Menurut Hartati bahwa pembinaan keluarga sakinah adalah menjalankan kewajiban masing-masing dengan baik saling menghargai dan menerima kekurangan dan kelebihan masing-masing. ${ }^{11}$

${ }^{9}$ Syarifuddin (45 tahun), warga masyarakat, Wawancara, di rumah warga, 23 Agustus 
Menurut A. Hidayat bahwa pembinaan keluarga sakinah adalah memberikan bimbingan sebelum menikah tentang cara-cara membangun keluarga yang harmonis agar bisa mencapai kebahagian dunia daan akhirat. ${ }^{12}$

Pemahaman masyarakat tentang keluarga sakinah sebahagian besar sudah memahami mengenai keluarga sakinah, namun dalam mengaflikasikan dalam kehidupan sehari-hari masih terdapat rumah tangga yang belum mencapai taraf berbagai faktor dan hambatan-hambatan yang sering terjadi dalam membina rumah tangga. Adapun upaya yang perlu ditempuh guna mewujudkan cita-cita kearah tercapainya keluarga sakinah. Upaya tersebut antara lain:

a. Mewujudkan harmonisasi hubungan antara suami istri.

b. Membina hubungan antara anggota kelurga dan lingkungan

c. Melaksanakan pembinaan kesejahteraan keluarga

d. Membina kehidupan beragama dalam rumah tangga

Upaya mewujudkan harmonisasi hubungan suami istri dapat tercapai antara lain meliputi:

a. Adanya saling pengertian

Diantara suami istri hendaknya saling memahami dan mengerti tentang keadaaan masing-masing, baik secara fisik maupun secara mental. Perlu diketahui bahwa suami istri sebagai manusia biasa, masing-masing memiliki kelebihan dan kekurangan, sebelumnya tidak saling mengenal, bertemu setelah sama-sama dewasa. Perlu dikeahui pula bahwa keduanya sebagai manusia tidak saja berbeda jenis tetapi masing-masing juga memiliki perbedaan sifat, sikap, tingkah laku dan masing-masing juga memiliki perbedaan pandangan.

b. Saling menerima kenyataan

Suami istri hendaknya sadar bahwa jodoh, rezeki dan mati itu dalam kekuasaan Allah, tidak dapat dirumuskan secara matematis. Namun kepada kita semua diperintahkan untuk melakukan ikhtiar, hasilnya barulah sebuah kenyataan yang harus kita terima termasuk keadaan suami atau istri kita masing-masing kita terima secara tulus dan ikhlas.

c. Penyusuain diri dalam keluarga

Penyesuain diri dalam keluarga berarti setiap anggota keluarga berusaha untuk saling mengisi kekurangan yang ada pada masing-masing, serta mau menerima dan mengakui kelebihan-kelebihan yang ada pada diri orang lain dalam lingkungan keluarga. Kemampuan penyusuain diri oleh masing-masing anggota keluarga mempunyai dampak-dampak yang positif, baik bagi pembinaan keluarga maupun masyarakat dan bangsa.

\footnotetext{
${ }^{10}$ Hartati (43 tahun), warga masyarakat, Wawancara, di rumah warga, 23 Agustus 2018

${ }^{11}$ A. Hidayat (47 tahun), Warga masyarakat, Wawancara, di rumah warga, 23 Agustus 


\section{d. Memupuk rasa cinta}

Setiap pasangan suami istri menginginkan hidup bahagia. Kebahagian hidup adalah bersifat relatif sesuai dengan cita rasa dari keperluannya, namun demikian setiap orang berpendapat bahwa kebahagian adalah segala sesuatu yang dapat mendatangkan ketentraman, keamanan dan kedamaian serta segala sesuatu yang bersifat pemenuhan kebutuhan mental spritual manusia. Untuk dapat mencapai kebahagian keluarga, hendaknya antara suami istri senantiasa berupaya memupuk rasa cinta dengan rasa saling harga menghargai dan penuh keterbukaan.

e. Melaksanakan asas musyawarah

Dalam kehidupan berkeluarga, sikap bermusyawarah terutama antara suami dan istri, merupakan sesuatu yang perlu ditarapkan. Hal tersebut sesuai dengan prinsip bahwa tak ada masalah yang tidak dapat dipecahkan selama prinsip musyawarah diamalkan. Dalam hal ini dituntut sikap terbuka, lapang dada, jujur, mau menerima, dan memberi serta sikap tidak menang sendiri dari pihak suami maupun istri. Sikap suka bermusyawarah dalam keluarga dapat menumbuhkan rasa memiliki dan rasa tanggung jawab diantara para anggota keluarga dalam menyelesaikan dan memecaahkan masalah-masalah yang timbul.

f. Suka memaafkan

Diantara suami istri harus ada sikap kesediaan untuk saling memaafkan atas kesalahan masing-masing. Hal ini penting karena tidak jarang persoalan yang kecil dan sepele dapat menjadi sebab terganggunya hubungan suami istri dan menjadi perselisihan yang berkepanjangan.

g. Berperang serta untuk kemajuan bersama

Masing-masing suami istri harus berusaha saling membantu pada setiap usaha untuk peningkatan dan kemajuan bersama yang pada gilirannya menjadi kebahagian keluarga.

h. Membina hubungan antara keluarga dan lingkungan

Keluarga dalam lingkup yang lebih besar tidak hanya terdiri dari ayah, ibu dan dan anak (muclear family) akan tetapi menyangkut hubungan persaudaraan yag lebih besar lagi (extented family), baik hubungan antara anggota keluarga maupun hubugan dengan lingkungan masyarakat.

1. Hubungan antara anggota keluarga

Hubungan antara anggota keluarga merupakan hubungan persaudaraan yang lebih luas menjadi ciri dari masyarakat kita, hubungan diantara sesama keluarga besar harus terjalin dengan baik antara keluarga dari kedua belah pihak. Suami harus baik hubungannya dengan pihak keluarga istri, demikian pula sebaliknya istri harus hubungannya baik dengan pihak keluarga suami. 
2. Hubungan dengan tetangga dan masyarakat

Tetangga merupakan orang-orang yang terdekat yang umumnya merekalah orang yang pertama tahu dan dimintai pertolongannya. Oleh karena itu sangatlah janggal kalau hubungan dengan tetangga tidak mendapat perhatian.

Dapat kita bayangkan kalau sebuah keluarga yang tidak mau rukun dengan tetangganya, kemudian mengalami musibah yang memerlukan pertolongan orang lain, sedangkan tetangganya tidak mau urusannya. Saling kunjung mengunjungi adalah perbuatan terpuji lainnya terhadap tetangga, perbuatan tersebut akan menimbulkan rasa kasih sayang antara yang satu dan yang lainnya. Begitu pentingnya hubungan dengan sesama, karena pada dasarnya sehingga manusia itu saling membutuhkan satu sama lain.

i. Melaksanakan pembinaan kesejahteraan keluarga

Dalam membina kebahagiaan dan kesejahteraan keluarga ada beberapa upaya yang dapat di tempuh, antara lain dengan cara melaksanakan:

1. Sepuluh program pokok PKK

2. Keluarga berencana

3. Usaha perbaikan gizi keluarga (UPGK)

4. Imuisasi

5. Bina keluarga balita

6. Air susu ibu (ASI)

a) Sepuluh program pokok PKK

1) Penghayatan dan pengalaman pancasila, dimaksudkan agar dapat mewujudkan keluarga yang memiliki jiwa, sikap dan tingkah laku berdasarkan pancasila.

2) Gotong royong, bertujuan untuk mengembangkan perbuatan luhur yang mencerminkan sikap dan suasana kekeluargaan dan kebersamaan sesuai dengan perkembangan ilmu pengetahuan dan teknologi.

3) Sandang, bertujuan untuk memberikan pengertian tentang fungsi dan cara berpakaian yang sesuai dengan agama dan kepribadian bangsa.

4) Pangan, dimaksudkan untuk menanamkan kesadaran betapa pentingnya makanan sehari-hari yang sehat dan penuh gizi serta halal untuk pertumbuhan dan kesehatan baik jasmani maupun rohani dalam membentuk keluarga sehat, cerdas dan kuat.

5) Perumahan dan tata laksana rumah tangga. Perumahan berfungsi sebagai tempat berteduh dan berlindung serta dapat memberikan rasa hidup tentram, aman dan bahagia.

6) Pendidikan dan keterampilan sangat erat hubungannya dengan pembentukan manusia indonesia seutuhnya berdasarkan pancasila.

7) Kesehatan adalah syarat mutlak untuk kebahagiaan hidup karena itu perlu dihayati apa arti dan bagaimana cara memelihara kesehatan baik pribadi maupun keluarga, termasuk kesehatan lingkungan. 
8) Mengembangkan kehidupan berkoperasi. Koperasi merupakan dasar dari demokrasi ekonomi yang dilaksanakan dari, oleh dan untuk masyarakat

9) Kelestarian lingkungan hidup, bertujuan agar antara lingkungan keluarga dengan lingkungan sekitarnya terdapat keserasian sehingga dirasakan adanya suasana tenang, tentram, hidup rukun, damai dalam lingkungan keluarga maupun dalam kehidupan bertetangga.

Perencanaan sehat bagi keluarga meliputi urusan keseimbangan pendapatan dan belanja rumah tangga, pengaturan waktu, pembagian tugas antara keluarga sesuai kemampuan masing-masing.

\section{PENUTUP}

Berdasarkan paparan di atas, maka dapat disimpulkan bahwa pemahaman masyarakat tentang keluarga sakinah sebahagian besar sudah memahami, namun dalam mengaflikasikan dalam kehidupan sehari-hari masih terdapat rumah tangga yang belum mencapai taraf kehidupan keluarga yang sejahtera sakinah mawaddah warahmah. Disebabkan oleh berbagai faktor dan hambatan-hambatan yang sering terjadi dalam membina rumah tangga. Diharapkan bagi calon pengantin agar mampu mengaplikasikan ilmu dan wawasan pengetahuan yang diperoleh melalui bimbingan perkawinan yang dilaksanakan di Kantor Urusan Agama Kecamatan Rappocini Kota Makassar sehingga tujuan dari pernikahan itu yakni menginginkan keluarga yang sakinah mawaddah warahmah dapat tercapai. Juga diharapkan kepada para penyuluh dan seluruh yang terkait didalam pembinaan perkawinan bagi calon pengantin agar mampu mentransfer ilmu dan pengalaman sebagai bekal dalam menjalani kehidupan rumah tangga.

\section{DAFTAR PUSTAKA}

Atabik, Ahmad, Dari Konseling Perkawinan Menuju Keluarga Samara, dalam Jurnal Bimbingan Konseling Islam, Konseling Religi, Jurusan Dakwah, Volume 4, Nomor 2, 2013.

Gymanstiar, Abdullah, Membangun Keluarga Cet. II; Bandung: MQS Pustaka Grafika, 2002.

Hasdan, Sofyan, Merekat Kebahagiaan Keluarga, Cet. I; Jakarta: Khasanah Manusia Nusantara, 2004.

Kementerian Agama RI, Al-Quran dan Terjemahan, Direktorat Jenderal Bimbingan Masyarakat Islam, Direktorat Urusan Agama Islam dan Pembinaan Syariah Cet I; Jakarta: PT. Sinergi Pustaka Indonesia, 2012.

Mardiyanto, Khalilah, Romantika Perkawinan, Cet. I; Putra Pelajar, 2000.

Shihab, M.Quraish, Membumikan Al-Qur'an Cet. XI; Bandung: Mizan, 1995. 
Subdit Bina Keluarga Sakinah, Fondasi Keluarga Sakinah, Direktorat Bina KUA \& Keluarga Sakinah, Ditjen Bimas Islam Kemenag RI, 2017.

Thalib, Konsep Islami Pembinaan Keluarga Sakinah Penuh Berkah Cet I; Bandung: Irsyat Baitus Salam, 1999.

\section{Sumber Wawancara}

A. Hidayat (47 tahun), Warga masyarakat, Wawancara, di rumah warga, 23 Agustus 2018

Hartati (43 tahun), warga masyarakat, Wawancara, di rumah warga, 23 Agustus 2018

Syarifuddin (45 tahun), warga masyarakat, Wawancara, di rumah warga, 23 Agustus 2018 